Prepared in cooperation with the Michigan Department of Environmental Quality, Michigan Department of Transportation, U.S. Army Corps of Engineers, and U.S. Fish and Wildlife Service

\title{
Estimated Bankfull Discharge for Selected Michigan Rivers and Regional Hydraulic Geometry Curves for Estimating Bankfull Characteristics in Southern Michigan Rivers
}

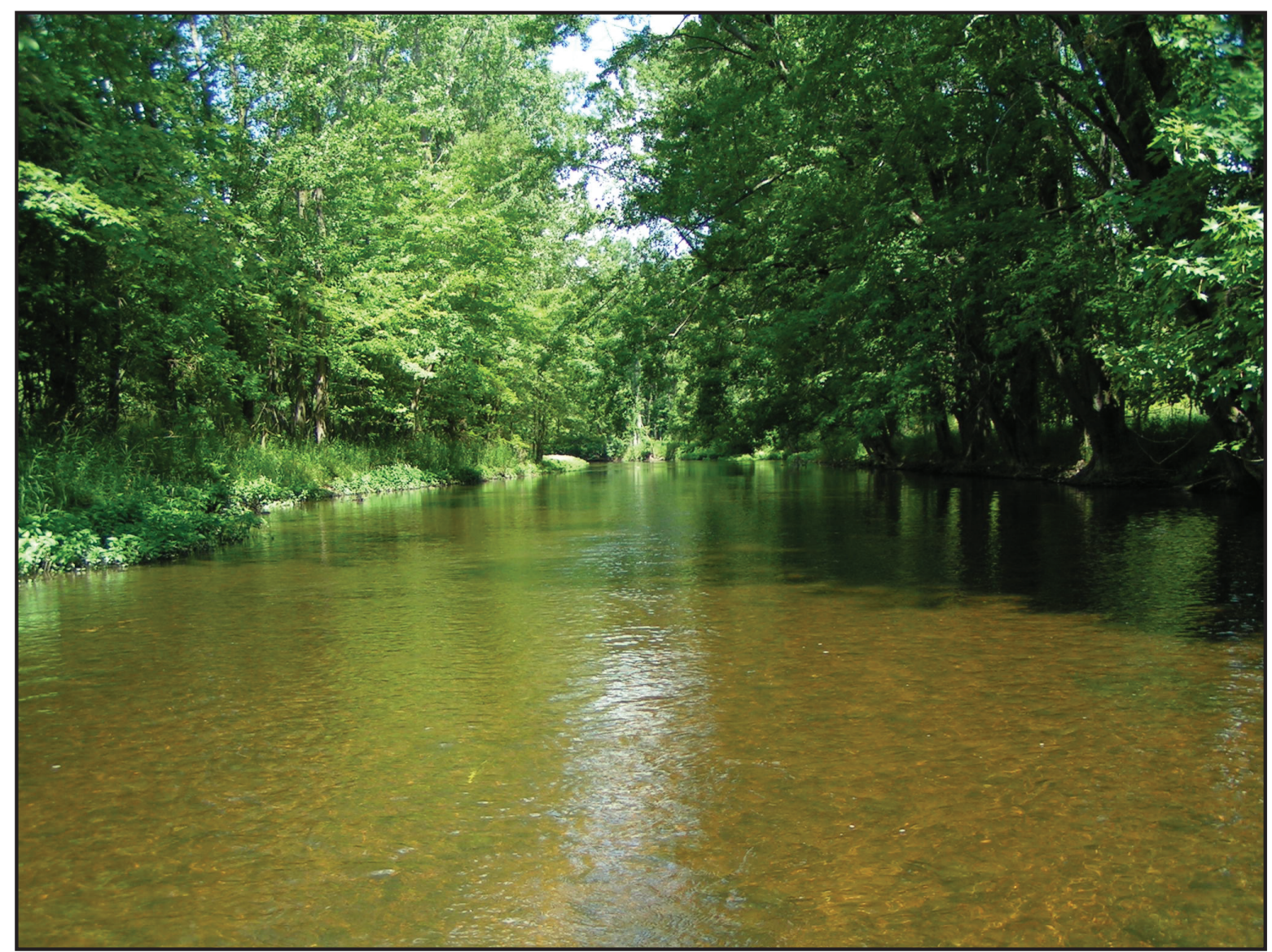

Scientific Investigations Report 2009-5133 
Cover: Looking Glass River near Eagle, Michigan, July 2007. (Photograph by C.M. Rachol, U.S. Geological Survey.) 


\section{Estimated Bankfull Discharge for Selected Michigan Rivers and Regional Hydraulic Geometry Curves for Estimating Bankfull Characteristics in Southern Michigan Rivers}

By Cynthia M. Rachol and Kristine Boley-Morse

Prepared in cooperation with the Michigan Department of Environmental Quality, Michigan Department of Transportation, U.S. Army Corps of Engineers, and U.S. Fish and Wildlife Service

Scientific Investigations Report 2009-5133

U.S. Department of the Interior

U.S. Geological Survey 


\section{U.S. Department of the Interior \\ KEN SALAZAR, Secretary \\ U.S. Geological Survey \\ Suzette M. Kimball, Acting Director}

U.S. Geological Survey, Reston, Virginia: 2009

For more information on the USGS—-the Federal source for science about the Earth, its natural and living resources,
natural hazards, and the environment, visit http://www.usgs.gov or call 1-888-ASK-USGS
For an overview of USGS information products, including maps, imagery, and publications,
visit http://www.usgs.gov/pubprod
To order this and other USGS information products, visit http://store.usgs.gov

Any use of trade, product, or firm names is for descriptive purposes only and does not imply endorsement by the U.S. Government.

Although this report is in the public domain, permission must be secured from the individual copyright owners to reproduce any copyrighted materials contained within this report.

Suggested citation:

Rachol, C.M., and Boley-Morse, Kristine, 2009, Estimated bankfull discharge for selected Michigan rivers and regional hydraulic geometry curves for estimating bankfull characteristics in southern Michigan rivers: U.S. Geological Survey Scientific Investigations Report 2009-5133, 300 p. 


\section{Acknowledgments}

The author would like to acknowledge the following people for their contributions to and support of this study. Field survey crews led by Jessica Mistak and Chris Freiburger of the Fisheries Division of the Michigan Department of Natural Resources, and by James Selegan of the Detroit District of the U.S. Army Corps of Engineers contributed data from several sites for use in this study. Additional field assistance was provided by Ralph Reznick and Matthew Staron, Michigan Department of Environmental Quality, Water Bureau; Heather Rawlings and Andrea Ania, U.S. Fish and Wildlife Service; Coreen Stryzalka, Michigan Department of Transportation; and Mary Weidel, U.S. Army Corps of Engineers.

Technical advice and expertise was provided by William Bartlett (USGS Surface Water Specialist, Northeast and Midwest Areas). Technical reviews of this report were performed by Carrie Huitger (Hydrologist, USGS Ohio Water Science Center) and Christiane Mulvihill (Physical Scientist, USGS New York Water Science Center). Editorial assistance was provided by Elizabeth Ciganovich (Technical Editor, USGS Columbus Publishing Service Center). Bureau approval was granted by Dorothy Tepper (USGS Eastern Region Report Approving Official). 


\section{Contents}

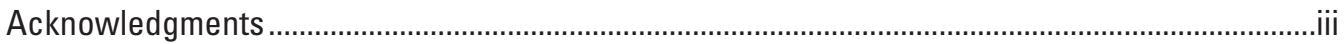

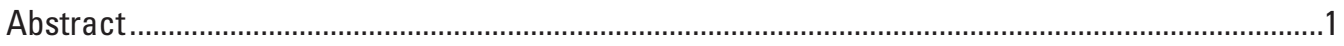

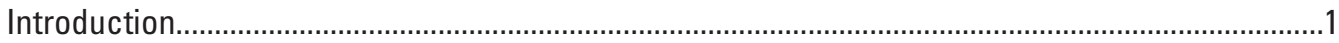

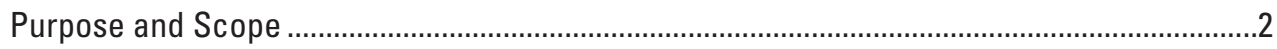

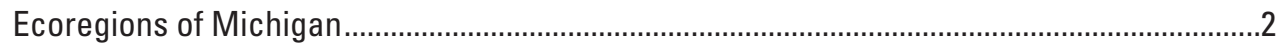

Regional Hydraulic Geometry Curves and Their Applications ................................................

Methods

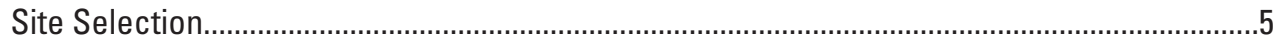

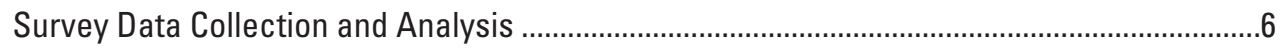

Bankfull Discharge Comparison to Flood-Frequency Statistics .....................................................12

Regional Hydraulic Geometry Curves ......................................................................................

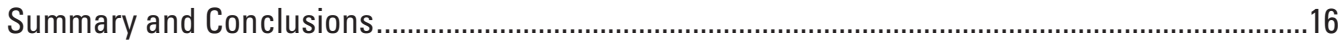

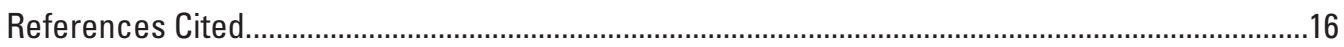

(Appendixes 1 through 3-2 are available as separate downloadable PDF files through links on the HTML index page at http://pubs.usgs.gov/sir/2009-5133/

Appendix 1. Longitudinal-profile survey data ..........................................................................19

Appendix 2-1. Riffle cross-section survey data used for regional curve development and bankfull discharge estimation......................................................................103

Appendix 2-2. Ancillary riffle cross-section survey data.........................................................159

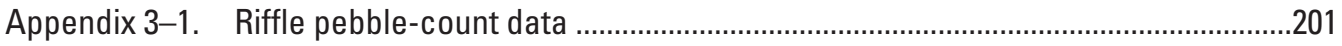

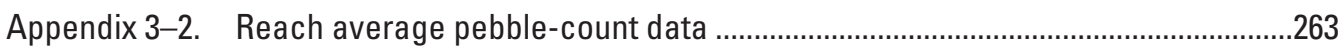

\section{Figures}

1. Map showing surveyed streamgage locations and Albert Ecoregions in Michigan ........3

2. Maps showing glacial drift thickness and texture, land-surface elevation, and 2001 land-cover distribution in Michigan

3-5. Photographs showing:

3. Unstable banks at U.S. Geological Survey streamgage 04153500 Salt River near North Bradley, Michigan

4. Unstable banks at USGS streamgage 04153500 Salt River near North Bradley, Michigan .

5. Vegetated sandbar formed from material deposited as a result of bank erosion at USGS streamgage 04153500 Salt River near North Bradley, Michigan .................6

6. Graph showing longitudinal profile data collected at USGS streamgage 04161580 Stony Creek near Romeo, Michigan

7. Graph showing riffle cross-section data collected at USGS streamgage 04161580 Stony Creek near Romeo, Michigan 
8. Schematic diagram of generic reach average pebble-count survey distribution based upon available stream features

9-11. Graphs showing:

9. Comparison of riffle cross-section data collected at USGS streamgage 04046000 Black River near Garnet, Michigan, by two independent survey teams.

10. Regional bankfull width, depth, and area curves for the Southern Lower Michigan Ecoregion

11. Regional bankfull discharge curve for the Southern Lower

Michigan Ecoregion

\section{Tables}

1. Surveyed streamgages, drainage area, riffle geometry summary, and watersurface slope for the Southern Lower Michigan Ecoregion

2. Surveyed streamgages, drainage area, riffle geometry summary, and watersurface slope for the Northern Lacustrine-Influenced Lower Michigan Ecoregion

3. Surveyed streamgages, drainage area, riffle geometry summary, and watersurface slope for the Northern Lacustrine-Influenced Upper Michigan and Wisconsin Ecoregion

4. Surveyed streamgages, drainage area, riffle geometry summary, and watersurface slope for the Northern Continental Michigan, Wisconsin, and Minnesota Ecoregion

5. Comparison of survey data collected at USGS streamgage 04046000 Black River near Garnet, Michigan

6. Surveyed streamgages, estimated bankfull discharge, and discharge-recurrence interval for the Southern Lower Michigan Ecoregion....

7. Surveyed streamgages, estimated bankfull discharge, and discharge-recurrence interval for the Northern Lacustrine-Influenced Lower Michigan Ecoregion.

8. Surveyed streamgage, estimated bankfull discharge, and discharge-recurrence interval for the Northern Lacustrine-Influenced Upper Michigan and Wisconsin Ecoregion

9. Surveyed streamgaging stations, estimated bankfull discharge, and dischargerecurrence interval for the Northern Continental Michigan, Wisconsin, and Minnesota Ecoregion 


\section{Conversion Factors and Datum}

\begin{tabular}{lcl}
\hline \multicolumn{1}{c}{ Multiply } & \multicolumn{1}{c}{ By } & \multicolumn{1}{c}{ To obtain } \\
\hline inch (in.) & Length & \\
foot (ft) & 25.4 & millimeter $(\mathrm{mm})$ \\
mile (mi) & 0.3048 & meter $(\mathrm{m})$ \\
millimeter $(\mathrm{mm})$ & 1.609 & kilometer $(\mathrm{km})$ \\
& 0.039 & inch (in.) \\
\hline square foot $\left(\mathrm{ft}^{2}\right)$ & Area & \\
square mile $\left(\mathrm{mi}^{2}\right)$ & 0.09290 & square meter $\left(\mathrm{m}^{2}\right)$ \\
\hline & 2.590 & square kilometer $\left(\mathrm{km}^{2}\right)$ \\
\hline cubic foot per second $\left(\mathrm{ft}^{3} / \mathrm{s}\right)$ & Flow rate & \\
\hline
\end{tabular}

Horizontal coordinate information is referenced to the North American Datum of 1983 (NAD 83).

\section{Abbreviations and Acronyms}

$\begin{array}{ll}\text { CCCD } & \text { Calhoun County Conservation District } \\ \text { DA } & \text { Drainage Area } \\ \text { D84 } & 84^{\text {th }} \text { percentile particle size } \\ \text { MDE0 } & \text { Michigan Department of Environmental Quality } \\ \text { MDNR } & \text { Michigan Department of Natural Resources } \\ \text { MD0T } & \text { Michigan Department of Transportation } \\ \text { R }^{2} & \text { Coefficient of determination } \\ \text { USACE } & \text { U.S. Army Corps of Engineers } \\ \text { USFWS } & \text { U.S. Fish and Wildlife Service } \\ \text { USGS } & \text { U.S. Geological Survey }\end{array}$




\title{
Estimated Bankfull Discharge for Selected Michigan Rivers and Regional Hydraulic Geometry Curves for Estimating Bankfull Characteristics in Southern Michigan Rivers
}

\author{
By Cynthia M. Rachol and Kristine Boley-Morse
}

\section{Abstract}

Regional hydraulic geometry curves are power-function equations that relate riffle dimensions and bankfull discharge to drainage-basin size. They are defined by data collected through surveys conducted at stable stream reaches and can be used to aid watershed managers, design engineers, and others involved in determination of the best course of action for an unstable stream. Hydraulic geometry curves provide a mechanism through which comparisons can be made between riffle dimensions collected at an unstable stream to those collected at stable streams within the same region. In 2005, a study was initiated to delineate regional hydraulic geometry curves for Michigan. After in-office review of 343 U.S. Geological Survey streamgaging stations and an extensive field reconnaissance effort, 44 stable reaches were selected for this study. Detailed surveys that included cross-sectional and longitudinal profiles and pebble counts were conducted at selected streamgages, which were distributed throughout Michigan. By use of survey data from riffle cross sections and water-surface slope, bankfull discharge was estimated and compared to flood-recurrence intervals using regional flood equations. This comparison shows that bankfull discharges in Michigan recur more frequently than every 2 years.

Regional hydraulic geometry curves were developed rather than statewide curves owing to large differences in factors that control channel geometry across the State. However, after the data were subdivided according to ecoregions, it was determined that there were enough data to delineate regional hydraulic geometry curves only for the Southern Lower Michigan Ecoregion. For this ecoregion, geometry curve equations and their coefficients of determination are:

$$
\begin{gathered}
\text { Width }=8.19 \times \mathrm{DA}^{0.44} ; \mathrm{R}^{2}=0.69, \\
\text { Depth }=0.67 \times \mathrm{DA}^{0.27} ; \mathrm{R}^{2}=0.28, \\
\text { Area }=4.38 \times \mathrm{DA}^{0.74} ; \mathrm{R}^{2}=0.59,
\end{gathered}
$$

where

$$
\begin{array}{cl}
\text { DA } & \text { is the drainage area and } \\
\mathrm{R}^{2} & \text { is the coefficient of determination. }
\end{array}
$$

By use of discharge estimates for the Southern Lower Michigan Ecoregion, a bankfull discharge curve was delineated. The corresponding equation and its coefficient of determination are:

$$
\text { Discharge }=4.05 \times \mathrm{DA}^{0.95} ; \mathrm{R}^{2}=0.60 .
$$

\section{Introduction}

In 2005, representatives from Federal, State, and county agencies formed a river-morphology interest group called the Michigan Stream Team. The goals of this team were to discuss research interests, share ideas and expertise, and establish a common data collection protocol and training program related to river morphology. From the start, there was a collective interest within this group to establish regional hydraulic geometry curves that could be used throughout the various regions of Michigan. These curves are power-function equations that relate riffle cross-section dimensions for width, depth, and area and an index discharge to drainage area. Data used to generate these curves are collected at river reaches that are stable and that have basin characteristics representative of the region. Hydraulic geometry curves provide a mechanism for permitting entities, watershed managers, design engineers, and others involved in stream-restoration activities to compare riffle dimensions collected at an unstable stream to those collected at stable streams within the same region. Often, historic crosssection and flow data are not available for a given impaired stream for the time period before restoration is needed. By use of hydraulic geometry curve equations, design decisions can be made as to appropriate dimensions for any particular drainage area. In cooperation with the Michigan Department of Environmental Quality (MDEQ), Michigan Department of Transportation (MDOT), U.S. Army Corps of Engineers (USACE), and U.S. Fish and Wildlife Service (USFWS), the U.S. Geological Survey (USGS) and Calhoun County Conservation District (CCCD) collected and analyzed the data needed to produce these curves for the Southern Lower Michigan Ecoregion (SLME). 


\section{Purpose and Scope}

The purpose of this report is to document data collected as a collaborative effort between the USGS and the CCCD, provide estimations of bankfull discharge for the stream reaches surveyed, and present regional geometry curves developed for the SLME. Detailed surveys were conducted that included cross-sectional and longitudinal profiles and pebble counts. Riffle channel geometries were interpreted from field survey data and used for the estimation of bankfull discharge. This discharge was related to flood-frequency return intervals identified by the MDEQ. Nonlinear regression models were used to generate the power-function equations for regional hydraulic geometry curves of bankfull width, mean bankfull depth, bankfull cross-sectional area, and bankfull discharge based on drainage-area size.

The data collected for this project are sufficient to categorize each survey location by use of the Rosgen classification system (Rosgen, 1994). Use of this classification system is not addressed in this report. However, an in-depth discussion of the Rosgen classification system and its application to this dataset is included in Boley-Morse (2009). Although Michigan has four ecoregions, data are sufficient for regression analysis only within the SLME (fig. 1).

\section{Ecoregions of Michigan}

The geometry of a river is a function of the surrounding landscape, including bedrock geology, surficial features, sediment supply, climate, human land uses, and vegetative cover. To accurately predict river dimensions based on surveyed rivers, a regional hydraulic geometry curve should in some way take into account these controlling factors. For this study, ecoregions were used to stratify the survey data to account for the influence of these factors. Ecoregions are geographically distinct areas that are distinguished from each other by abiotic characteristics such as climate, bedrock geology, glacial landforms, and soils and by biotic characteristics such as plants, animals, and microbes. For this study, regional landscape ecoregions of Michigan, Minnesota, and Wisconsin developed by Albert (1995) were used (fig. 1). Under this classification system, there are four ecoregions in Michigan: Southern Lower Michigan; Northern Lacustrine-Influenced Lower Michigan; Northern Lacustrine-Influenced Upper Michigan and Wisconsin; and Northern Continental Michigan, Wisconsin, and Minnesota.

The SLME encompasses the entire southern half of Michigan's Lower Peninsula. It is characterized by flat to moderately sloped glacial drift plains and till that range in thickness from 100 to $600 \mathrm{ft}$ (fig. 2; Soller and Packard, 1998; Passero and others, 1981). Flat plains of lake-bed clays line the southeastern edge of the Lower Peninsula from its border with Ohio to the Saginaw Bay area and mark areas previously inundated by glacial lakes. This ecoregion is the wettest of the four, with records from 1977 to 2000 showing that the annual average precipitation is 34 in. per year (Daly and others, 2002). The southeastern corner of Michigan contains the most populated and developed areas in the State, and many natural rivers are channelized and prone to discharges highly affected by treated wastewater and event stormwater (Francis and Haas, 2006). In addition, this ecoregion contains the 60 most populated cities within the State, far surpassing the population of the other three ecoregions combined (Michigan Information Center, 2001). This concentration affects the local hydrology through urbanization, residential development, and agricultural development, increasing impervious surfaces and changing the geomorphology. Other parts of this ecoregion are characterized by agricultural fields with streams that have been straightened and otherwise heavily modified to accommodate additional inflow from drainage ditches.

The northern part of the Lower Peninsula is within the Northern Lacustrine-Influenced Lower Michigan Ecoregion. This part of the State is characterized by rolling hills and steep-sloped uplands of glacial drift that can be up to $1,000-\mathrm{ft}$ thick (Soller and Packard, 1998; Passero and others, 1981). It is dominated more by forest than agriculture although isolated pockets of farmland can be found, particularly orchards and vineyards in the northwestern corner. Most of the State's larger inland lakes are located within this ecoregion. Records from 1977 to 2000 show that this ecoregion has an average annual precipitation of 31.9 in. per year (Daly and others, 2002), which is somewhat less than the Southern Lower Michigan Ecoregion.

There are two ecoregions in the Upper Peninsula of Michigan: the Northern Lacustrine-Influenced Upper Michigan and Wisconsin Ecoregion, which includes the eastern part of the peninsula; and the Northern Continental Michigan, Wisconsin, and Minnesota Ecoregion, which includes the western part of the peninsula to Wisconsin (Albert, 1995). Within the Northern Lacustrine-Influenced Upper Michigan and Wisconsin Ecoregion, the bedrock is composed of sediments deposited in shallow-sea conditions. These units were eroded by glaciers, and the glacial drift that was deposited in moraines was reworked by glacial lakes that inundated this part of the State. These sediments were later redeposited by lacustrine and aeolian processes (Bergquist, 1936). The resulting landscape consists of relatively flat, poorly draining, marshy sand plains (fig. 2). Precipitation records from 1977 to 2000 show that the annual average precipitation of 31.7 in. per year within this ecoregion is virtually identical to its Lower Peninsula counterpart (Daly and others, 2002). Dominant land-cover and land-use types include wetland, forest, and open water. 


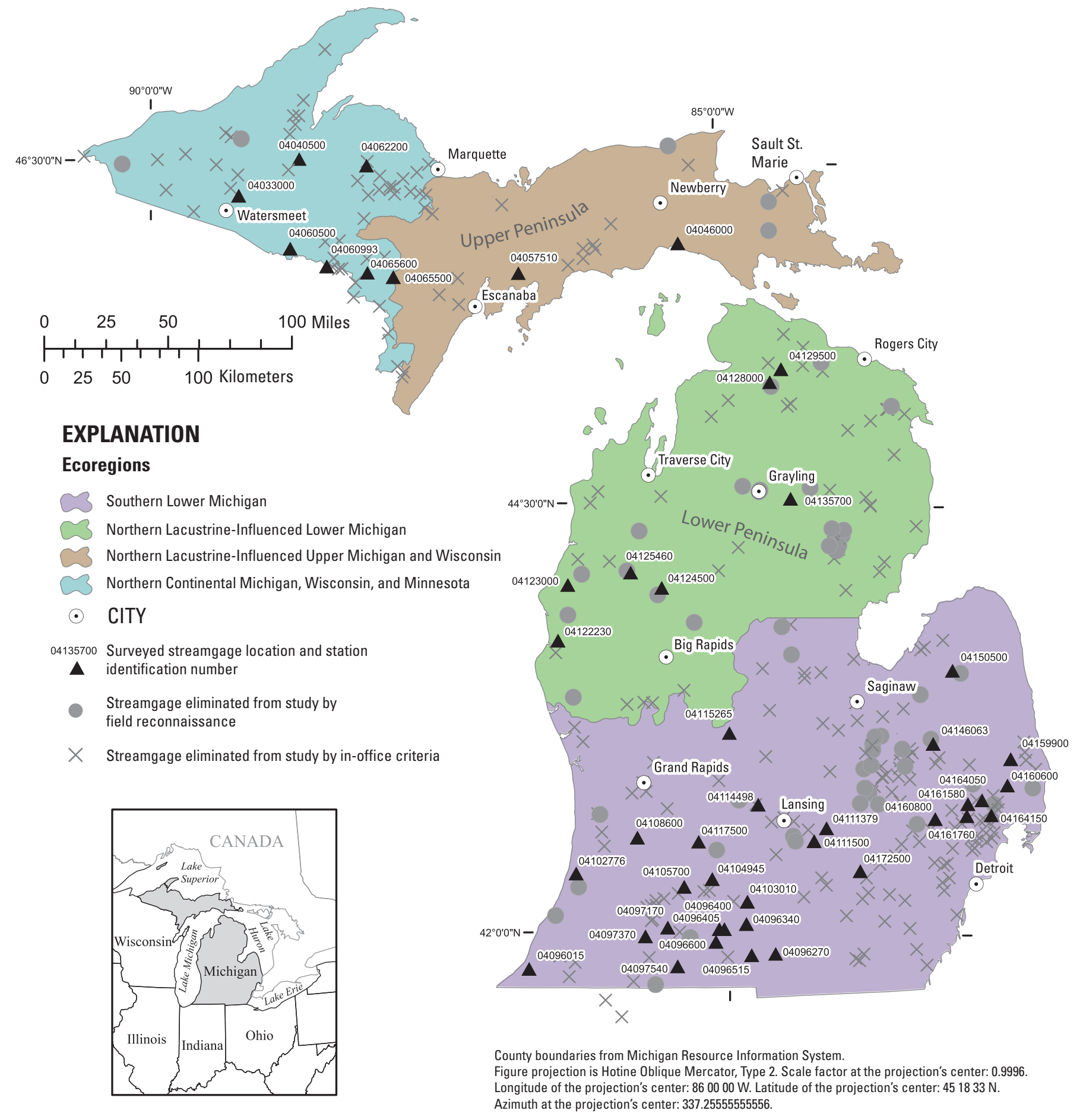

Figure 1. Surveyed streamgage locations and Albert Ecoregions (Albert, 1995) in Michigan. 

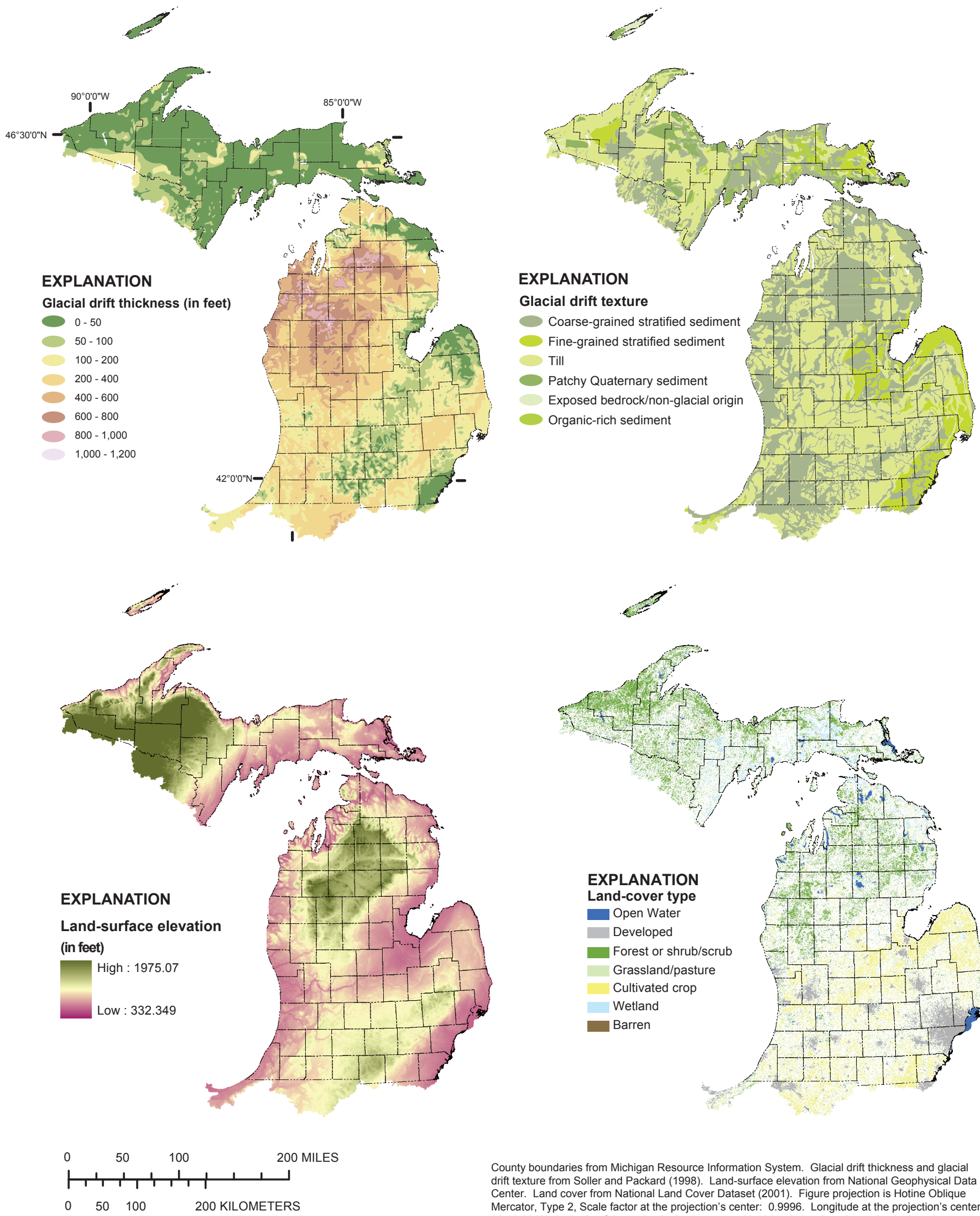

County boundaries from Michigan Resource Information System. Glacial drift thickness and glacial (1998). Land-surface elev Center. Land cover from National Land Cover Dataset (2001). Figure projection is Hotine Oblique Mercator, Type 2, Scale factor at the projection's center: 0.9996. Longitude at the projection's center: $860000 \mathrm{~W}$. Latitude of the projection's center: $451833 \mathrm{~N}$. Azimuth at the projection's center: 337.25555555556

Figure 2. Glacial drift thickness and texture, land-surface elevation, and 2001 land-cover distribution in Michigan. 
The western Upper Peninsula of Michigan is within the Northern Continental Michigan, Wisconsin, and Minnesota Ecoregion and consists of the outer reaches of the shallow-sea basin and underlying volcanic bedrock units that sometimes crop out through Quaternary sediments up to 400-ft thick (fig. 2; Soller and Packard, 1998). The Porcupine Mountains, the only mountains in Michigan, are within this ecoregion. They are composed of volcanic rock overlain by sandstone, shale, and conglomerates (Doonan and Henrickson, 1969). Major industries within this ecoregion are related to forestry, mining, tourism, and agriculture, which is mostly limited to livestock and dairy products. Records from 1977 to 2000 show that the annual average precipitation within this ecoregion is 32.4 in. per year (Daly and others, 2002).

\section{Regional Hydraulic Geometry Curves and Their Applications}

Regional hydraulic geometry curves, also commonly called "regional reference curves," are power-function equations that relate riffle dimensions and bankfull discharge to drainage-basin size. Hydraulic geometry equations and the relation of these equations to an index flow were first introduced by Leopold and Maddock (1953), and these equations have been the subject of recent advances in stream-channel design by Rosgen (1996). In common practice, field measurements of bankfull width, depth, and substrate character are made at stable stream reaches that are representative of streams within that particular area. It is expected that these stable reaches are appropriate reference stations and when data from them are combined with data collected at other reference stations, the combined data can be used to extrapolate channel geometry for sites where such data are not available (Rosgen, 1996). For this study, field survey data were collected at stable stream reaches near historical or current USGS streamgages and crest-stage gages. By relying on gaged stream locations, the relations observed and modeled through the hydraulic geometry curves can be transferred to sites where historical flow data and hydraulic geometry curves are unavailable. This practice can be used to verify the stability of a stream channel or estimate what stable stream-channel dimensions would need to be for a given drainage area. Streamflow records must have been collected at a given streamgage for 10 years or longer for the data to be included in a hydraulic geometry equation.

\section{Methods}

\section{Site Selection}

From the outset of this study, emphasis was placed on surveying stable stream reaches located at or near USGS streamgage sites. The advantage of these locations over ungaged sites was that channel geometry could be related to flood-recurrence intervals (in particular, the bankfull flow). With this in mind, current and discontinued continuous streamgages throughout Michigan were evaluated for this study. The survey goal was to collect data at every streamgage location that fit the study criteria and to build a statewide database for Michigan. For the purposes of this study, a stream reach is considered stable if the reach is at equilibrium, with no evident net gain or loss in sediment.

A two-step site-selection process was used to select streamgages with stable reaches for inclusion in this study. The initial step involved an "in-office" screening of 343 streamgages with a period of record greater than 10 years that also met the following criteria:

- artificial controls, such as dams upstream or a impoundment downstream of the station, do not affect flow at medium and high stages;

- the stream reach does not have known stability concerns, such as excessive channel or bank erosion or bed aggradation;

- the stream is able to adjust its shape and form; therefore, sites with bedrock banks and bed were not considered for this study;

- reference marks have not been destroyed and the streamgage datum could be reestablished for discontinued gages.

This initial screening eliminated 238 sites from the study (fig. 1).

The second step in the selection process involved a site reconnaissance to ensure that at least two reference marks could be used to relate surveys to the streamgage datum and that the study reach was suitable. Study reaches were defined for this study as two meander wavelengths or 20 times the bankfull width, whichever was less, and were within the vicinity of the streamgage such that no tributaries were entering the reach nor by-pass channels leaving the reach. Study reaches were field-checked, and sites with signs of channel instability were eliminated from consideration (fig. 1). Photographs collected at the Salt River near North Bradley, a discontinued streamgage location, illustrate features that indicate channel instability (figs. 3-5). Sixty-one sites were not used for this study owing to the elimination of streamgage-reference marks or because of conditions found during the site reconnaissance or both (fig. 1). 


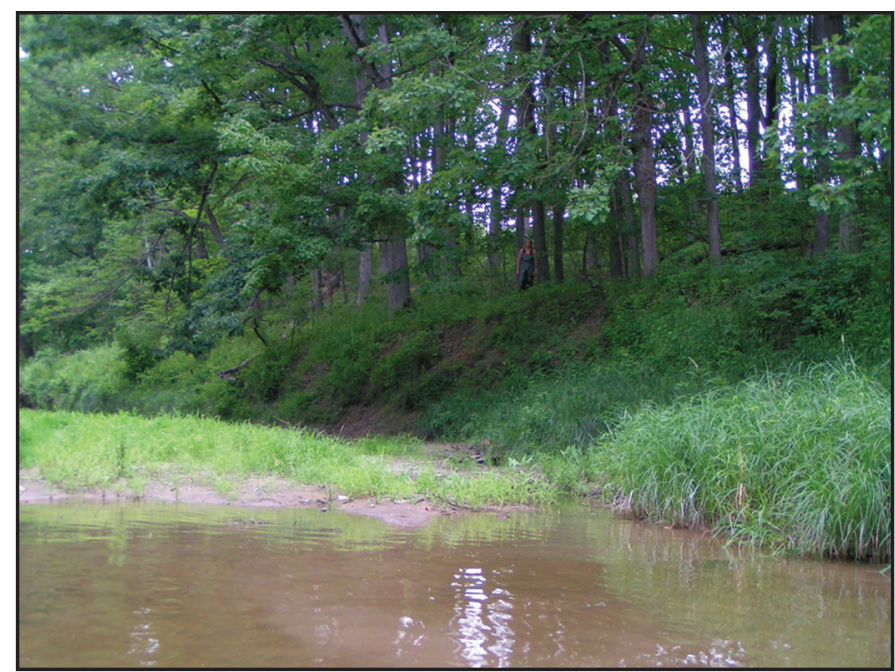

Figure 3. Unstable banks at U.S. Geological Survey streamgage 04153500 Salt River near North Bradley, Michigan. This stream is no longer connected with its flood plain, because it has banks 12 to 15 feet high. Sediment eroded from the bank is seen deposited at the base of the bank. (Photograph by C.M. Rachol, July 2008)

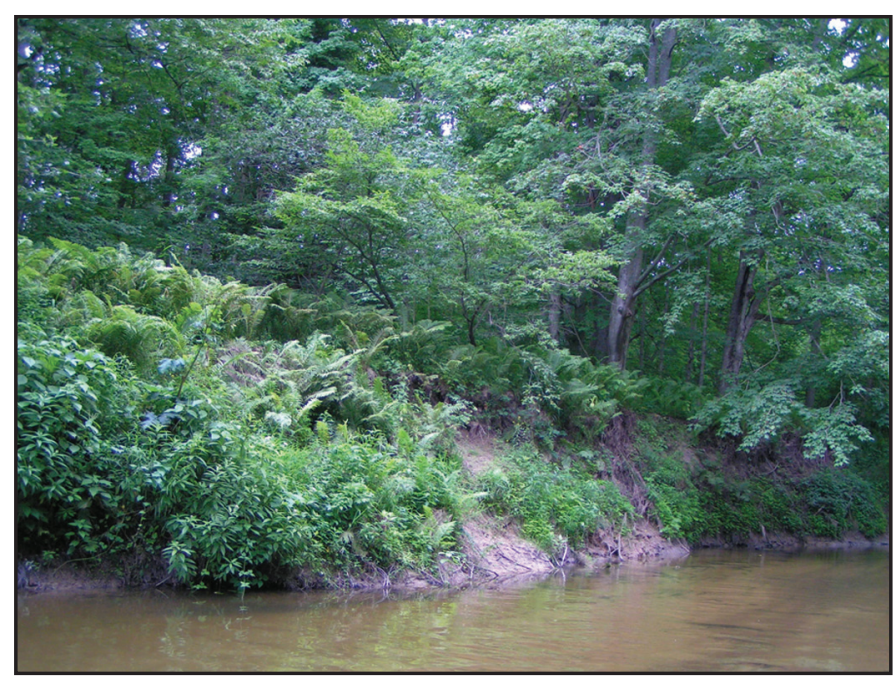

Figure 4. Unstable banks at U.S. Geological Survey streamgage 04153500 Salt River near North Bradley, Michigan. The eroded bank shown above is located directly across from the high bank shown in figure 3. (Photograph by C.M. Rachol, July 2008)

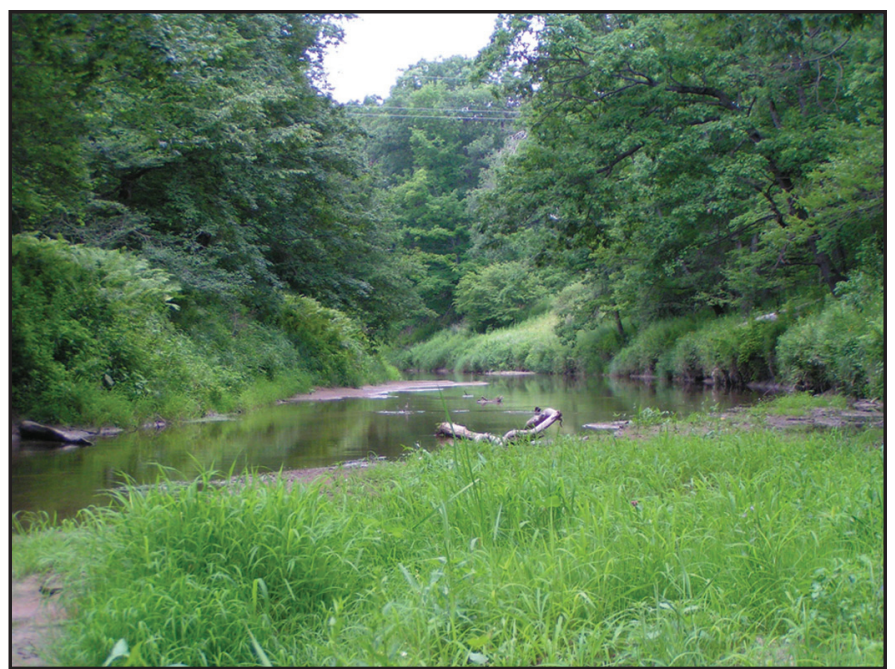

Figure 5. Vegetated sandbar formed from material deposited as a result of bank erosion at U.S. Geological Survey streamgage 04153500 Salt River near north Bradley, Michigan. Two more sandbars consisting of eroded material can be seen while standing on the vegetated sandbar shown above, facing downstream. (Photograph by C.M. Rachol, July 2008)

\section{Survey Data Collection and Analysis}

Survey data consisting of riffle cross sections, longitudinal profiles, and pebble counts were collected at stable stream reaches for this study by staff from the USGS, CCCD, MDNR, MDEQ, MDOT, USACE, and USFWS, by use of survey protocols developed by the Michigan Stream Team (Michigan Stream Team, 2005). A regional curve for the Menominee River Basin was developed by Mistak and Stille (2007); data from the sites surveyed were included in the database developed as part of this study and in the estimation of bankfull discharge. The study database contains data for the 43 streamgages that were analyzed. Although station 04115265 Fish Creek near Crystal met all study criteria, the data were not received in time for inclusion in this study. All previously unpublished data for this study are provided in appendixes 1-3.

In 2005, the MDEQ performed a peak-flow analysis of selected USGS streamgages and provided flood-recurrence estimates. In 2008, the MDEQ reran this analysis to include stations that were not part of the original 2005 analysis and to provide an expanded range of flood-recurrence intervals for some sites (Fongers, 2008). The peak-flow analysis was used as a guide for an approximate bankfull elevation by crossreferencing the 1.5-year and 2.0-year returns to a "bankfull" stage on the streamgage rating. By use of this stage, the height difference with observed water-surface elevation was calculated. During the surveying of the longitudinal profile, the bankfull indicator was rated by evaluating how closely it corresponded to the "calibrated bankfull" stage.

Surveyed longitudinal profiles were tied-in to the streamgage datum and included thalweg bed elevation, water depth, and bankfull elevation (fig. 6). Bankfull indicators were noted and given the following ratings. 


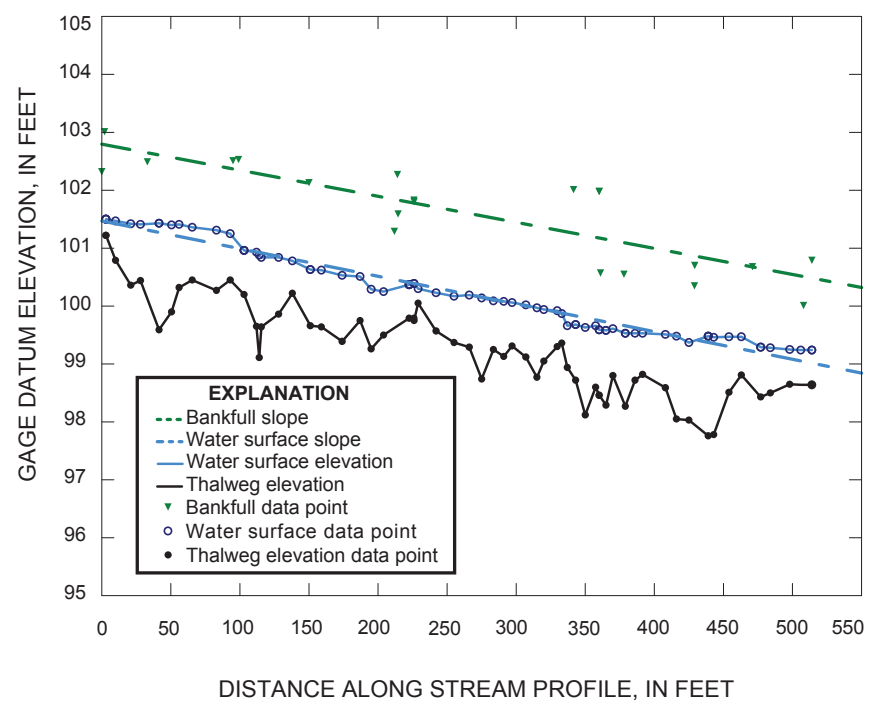

Figure 6. Longitudinal profile data collected at U.S. Geological Survey streamgage 04161580 Stony Creek near Romeo, Michigan.

1. "Excellent." Slope break between bank and floodplain is very clear and the floodplain elevation is consistent with other bankfull elevations along the longitudinal profile; compares well to the "calibrated bankfull," and sand deposition related to a recent event is present.

2. "Fair." Slope break may be occluded within thick brush or vegetation but is consistent with other bankfull elevations along the longitudinal profile and the "calibrated bankfull."

3. "Poor." Slope break between bank and floodplain is not consistent with other bankfull elevations and the "calibrated bankfull," the bankfull flat is not very wide before reaching a historical terrace, or nonideal bankfull indicators, such as changes in vegetation, are present.

As the longitudinal profile survey progressed at each site along the reach, it was noted whether the bed and bankfull elevations were consistent (maintaining a steadily decreasing slope) or whether there were indications that the bed was eroding (through sudden, larger than expected decreases in the slope) or aggrading (through a steadily increasing slope). In addition to noting the bankfull conditions, the general thalweg substrate was described, and a site sketch was drawn.

RiverMorph analysis software (version 4.3.0, RiverMorph LLC, 2001-07) was used to analyze the longitudinalprofile data. Thalweg, water-surface, and bankfull elevations identified from the cross-section surveys were also input into the longitudinal profile to provide additional bankfull data. Water-surface elevation was determined directly in RiverMorph by adding the water depth to the thalweg bed elevation measured during the field survey. From the input field data, a best-fit line representing the water surface and bankfull slopes through the study reach was interpolated by use of
RiverMorph. Water-surface slopes used for the calculation of bankfull discharge are presented in tables 1-4. Additional longitudinal profile data are presented in appendix 1.

Cross-section surveys were conducted from left bank to right bank and located to include bankfull-to-bankfull elevations on each side (fig. 7). In addition to bed elevation, general bed substrate was described and the water-surface elevation at each bank was surveyed. Site photographs were collected from mid-channel and facing upstream and downstream and towards left- and right-bank at the cross-section location. At the beginning of this study, three riffle and one pool crosssectional surveys were collected. After the first field season, the Michigan Stream Team discussed whether it was necessary to collect three riffle cross sections, and it was determined that the collection of a single riffle cross section would be sufficient for regional geometry curve development. Three riffle cross sections were surveyed during the first field season at 12 of the 43 study locations. RiverMorph analysis software was used to analyze the cross-section survey data and compile summary data (bankfull width, depth, and cross-sectional area; tables 1-4). During this analysis, it was determined that bankfull features identified in the field may actually represent a depositional berm adjacent to the river channel rather than the actual flood plain. This interpretation is similar to that made by Sherwood and Huitger (2005) during the delineation of hydraulic geometry curves for Ohio. As was done in the Ohio study, at cross sections in which the flood plain is at an elevation lower than the field-determined bankfull elevation, the bankfull elevation was adjusted downwards to match the flood-plain elevation. In appendix 2, these changes are denoted as "bankfull" when they refer to the adjusted elevation, and are denoted as "field-determined bankfull" when they refer to the original surveyed bankfull elevation. Cross-section data for USGS streamgage 04065500 Sturgeon River near Foster City is different from that presented in the MDNR Menominee River Basin regional curve report (Mistak and Stille, 2007) because three riffle cross sections were surveyed at this site as part of that study and the current study relied on a different cross section than that used in the Menominee River report. The cross section used was selected because it was the only one out of the three which extended onto the flood plain. Additional riffle cross-section survey data are presented in appendix 2; two sets of pebble-count data were collected at each site. A 100-pebble count was conducted at each riffle cross section from bankfull elevation to bankfull elevation, and a reach-average pebble count was conducted to apply the Rosgen classification system. This count was parsed out proportionally among representative features within the longitudinal-profile reach and ten pebbles were counted within each feature. For example, if the reach length consisted of 70-percent riffle and 30-percent pool, the reach-average pebble count was conducted so that 70 pebbles were counted within riffles and 30 within pools (fig. 8). Reach-average pebble-count data were collected at all surveyed sites except for USGS streamgage 04125460 Pine River at High School Bridge near Hoxeyville. Pebble-count data are presented in appendix 3. 
Table 1. Surveyed streamgages, drainage area, riffle geometry summary, and water-surface slope for the Southern Lower Michigan Ecoregion.

[USGS, U.S. Geological Survey; $\mathrm{mi}^{2}$, square mile; $\mathrm{ft}$, foot; $\mathrm{ft}^{2}$, square foot; MI, Michigan; water year is the 12-month period from October 1 through September 30. The water year is designated by the calendar year in which it ends]

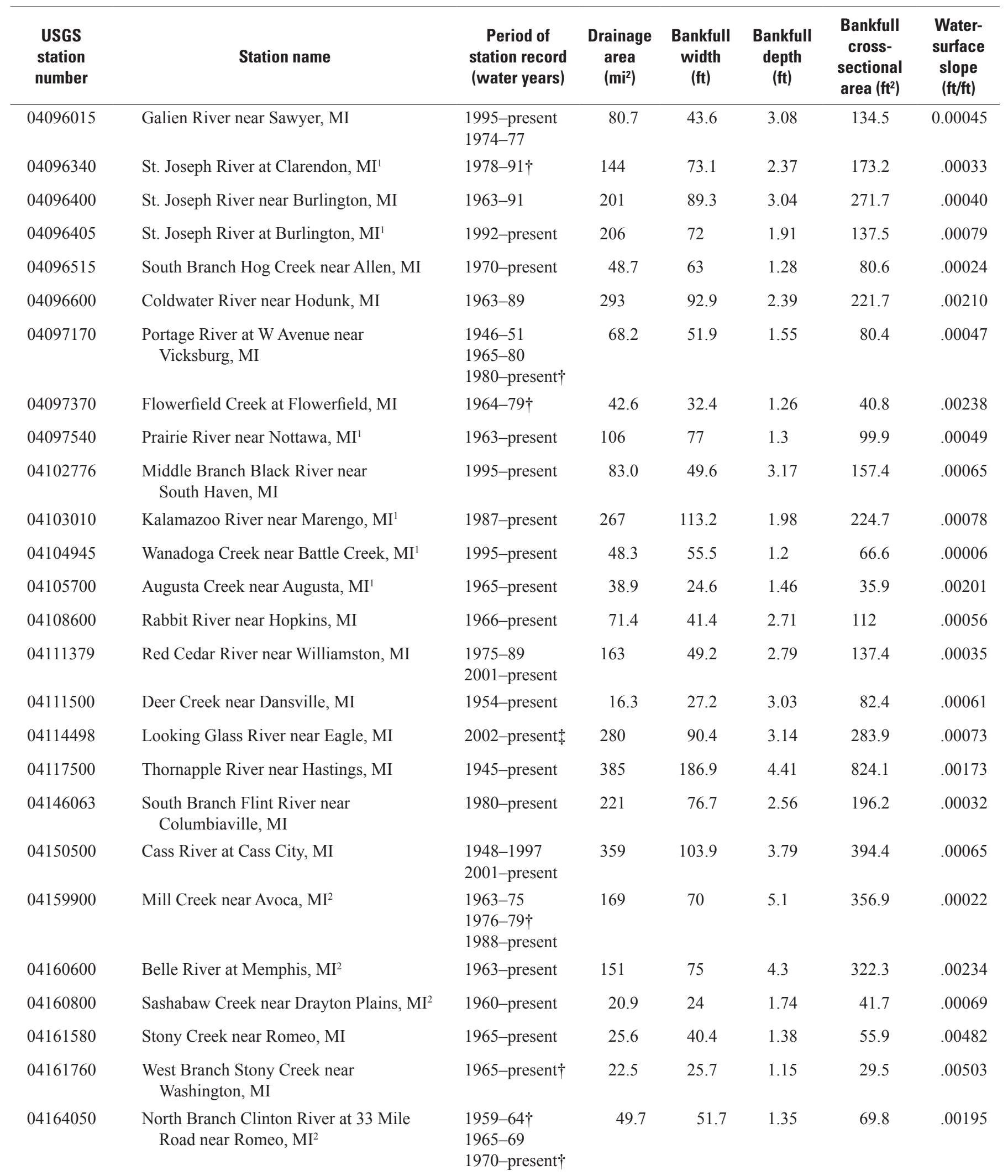


Table 1. Surveyed streamgages, drainage area, riffle geometry summary, and water-surface slope for the Southern Lower Michigan Ecoregion. - Continued

[USGS, U.S. Geological Survey; $\mathrm{mi}^{2}$, square mile; $\mathrm{ft}$, foot; $\mathrm{ft}^{2}$, square foot; MI, Michigan; water year is the 12-month period from October 1 through September 30. The water year is designated by the calendar year in which it ends]

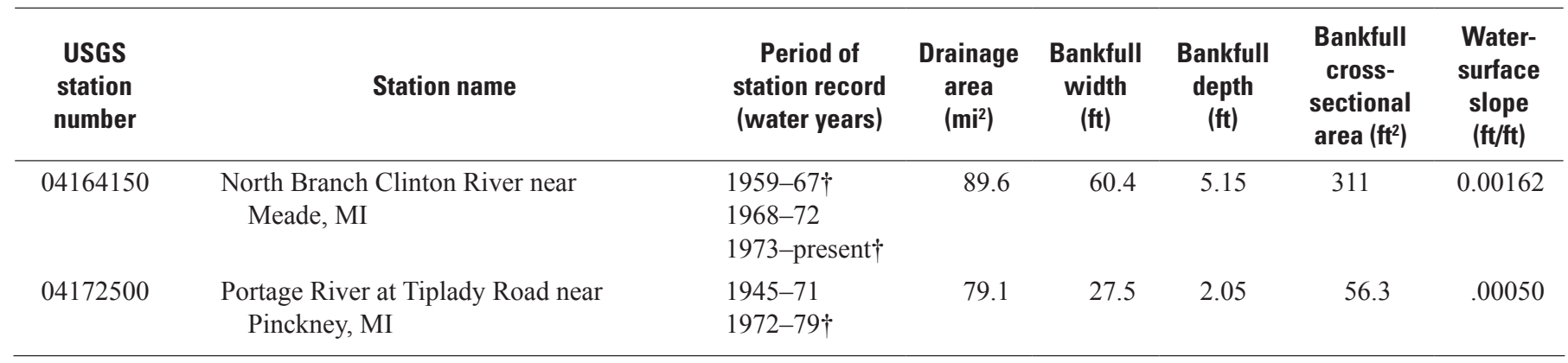

${ }^{1}$ Previously unpublished survey data collected by Calhoun County Conservation District and Michigan Department of Natural Resources.

${ }^{2}$ Previously unpublished survey data collected by Michigan Department of Natural Resources.

$\dagger$ Operated as a crest-stage partial-record station.

* Operated as 04114500 Looking Glass River near Eagle, MI (drainage area $=281 \mathrm{mi}^{2}$ ) from 1944-96; station was reestablished in October 2001 at its present location and the gaging-station record has been considered equivalent with that of the previous station.

Table 2. Surveyed streamgages, drainage area, riffle geometry summary, and water-surface slope for the Northern LacustrineInfluenced Lower Michigan Ecoregion.

[USGS, U.S. Geological Survey; $\mathrm{mi}^{2}$, square mile; $\mathrm{ft}$, foot; $\mathrm{ft}^{2}$, square foot; MI, Michigan; water year is the 12-month period from October 1 through September 30. The water year is designated by the calendar year in which it ends]

\begin{tabular}{|c|c|c|c|c|c|c|c|}
\hline $\begin{array}{c}\text { USGS } \\
\text { station } \\
\text { number }\end{array}$ & Station name & $\begin{array}{c}\text { Period of } \\
\text { station record } \\
\text { (water years) }\end{array}$ & $\begin{array}{c}\text { Drainage } \\
\text { area } \\
\left(\mathrm{mi}^{2}\right)\end{array}$ & $\begin{array}{l}\text { Bankfull } \\
\text { width } \\
\text { (ft) }\end{array}$ & $\begin{array}{c}\text { Bankfull } \\
\text { depth } \\
\text { (ft) }\end{array}$ & $\begin{array}{l}\text { Bankfull } \\
\text { cross- } \\
\text { sectional } \\
\text { area }\left(\mathrm{ft}^{2}\right)\end{array}$ & $\begin{array}{c}\text { Water- } \\
\text { surface } \\
\text { slope } \\
\text { (ft/ft) }\end{array}$ \\
\hline 04122230 & $\begin{array}{l}\text { North Branch Pentwater River near } \\
\text { Pentwater, MI }\end{array}$ & 1974-present $\dagger$ & 42.3 & 50 & 1.85 & 92.6 & 0.00068 \\
\hline 04123000 & Big Sable River near Freesoil, MI & $\begin{array}{l}1942-73 \\
1974-75 \dagger \\
2007-08 *\end{array}$ & 127 & 70 & 2.57 & 180.2 & .00088 \\
\hline 04124500 & East Branch Pine River near Tustin, MI & $\begin{array}{l}1952-63 \\
1963-91 \dagger \\
1991-\text { present }\end{array}$ & 60 & 35.2 & 2.70 & 95.1 & .00678 \\
\hline 04125460 & $\begin{array}{l}\text { Pine River at High School Bridge near } \\
\text { Hoxeyville, } \mathrm{MI}^{1}\end{array}$ & $\begin{array}{l}1952-82 \\
1996-\text { present }\end{array}$ & 245 & 64.4 & 3.34 & 215.2 & .00259 \\
\hline 04135700 & $\begin{array}{l}\text { South Branch Au Sable River near } \\
\text { Luzerne, MI }\end{array}$ & $\begin{array}{l}1951-66^{*} \\
1966-89 \\
1990-\text { present }\end{array}$ & 401 & 87.3 & 2.24 & 195.4 & .00155 \\
\hline
\end{tabular}

${ }^{1}$ Previously unpublished survey data collected by U.S. Army Corps of Engineers.

${ }^{2}$ Previously unpublished survey data collected by Michigan Department of Natural Resources.

$\dagger$ Operated as a crest-stage partial-record station.

* Miscellaneous measurement station. 
Table 3. Surveyed streamgages, drainage area, riffle geometry summary, and water-surface slope for the Northern LacustrineInfluenced Upper Michigan and Wisconsin Ecoregion.

[USGS, U.S. Geological Survey; $\mathrm{mi}^{2}$, square mile; $\mathrm{ft}$, foot; $\mathrm{ft}^{2}$, square foot; MI, Michigan; water year is the 12-month period from October 1 through September 30 . The water year is designated by the calendar year in which it ends]

\begin{tabular}{|c|c|c|c|c|c|c|c|}
\hline $\begin{array}{c}\text { USGS } \\
\text { station } \\
\text { number }\end{array}$ & Station name & $\begin{array}{c}\text { Period of } \\
\text { station record } \\
\text { (water years) }\end{array}$ & $\begin{array}{c}\text { Drainage } \\
\text { area } \\
\left(\mathrm{mi}^{2}\right)\end{array}$ & $\begin{array}{l}\text { Bankfull } \\
\text { width } \\
\text { (ft) }\end{array}$ & $\begin{array}{c}\text { Bankfull } \\
\text { depth } \\
\text { (ft) }\end{array}$ & $\begin{array}{l}\text { Bankfull } \\
\text { cross- } \\
\text { sectional } \\
\text { area }\left(\mathrm{ft}^{2}\right)\end{array}$ & $\begin{array}{l}\text { Water- } \\
\text { surface } \\
\text { slope } \\
\text { (ft/ft) }\end{array}$ \\
\hline 04046000 & Black River near Garnet, MI & $\begin{array}{l}1952-78 \\
1978-94 \dagger \\
1994-\text { present }\end{array}$ & 28 & 35.9 & 1.89 & 68 & 0.01788 \\
\hline
\end{tabular}

$\dagger$ Operated as a crest-stage partial-record station.

Table 4. Surveyed streamgages, drainage area, riffle geometry summary, and water-surface slope for the Northern Continental Michigan, Wisconsin, and Minnesota Ecoregion.

[USGS, U.S. Geological Survey; $\mathrm{mi}^{2}$, square mile; $\mathrm{ft}$, foot; $\mathrm{ft}^{2}$, square foot; MI, Michigan; water year is the 12-month period from October 1 through September 30. The water year is designated by the calendar year in which it ends]

\begin{tabular}{|c|c|c|c|c|c|c|c|}
\hline $\begin{array}{l}\text { USGS } \\
\text { station } \\
\text { number }\end{array}$ & Station name & $\begin{array}{c}\text { Period of } \\
\text { station record } \\
\text { (water years) }\end{array}$ & $\begin{array}{c}\text { Drainage } \\
\text { area } \\
\left(\mathrm{mi}^{2}\right)\end{array}$ & $\begin{array}{c}\text { Bankfull } \\
\text { width } \\
\text { (ft) }\end{array}$ & $\begin{array}{c}\text { Bankfull } \\
\text { depth } \\
\text { (ft) }\end{array}$ & $\begin{array}{c}\text { Bankfull } \\
\text { cross- } \\
\text { sectional } \\
\text { area }\left(\mathrm{ft}^{2}\right)\end{array}$ & $\begin{array}{c}\text { Water- } \\
\text { surface } \\
\text { slope } \\
\text { (ft/ft) }\end{array}$ \\
\hline 04033000 & Middle Branch Ontonagon near Paulding, MI & $\begin{array}{l}1943-95 \\
\text { 2001-present }\end{array}$ & 164 & 70.2 & 2.72 & 190.7 & 0.00302 \\
\hline 04060500 & Iron River at Caspian, $\mathrm{MI}^{1}$ & $\begin{array}{l}1948-1980 \\
2005-\text { present }\end{array}$ & 92.1 & 48.8 & 3.12 & 152.2 & .00277 \\
\hline 04060993 & $\begin{array}{l}\text { Brule River at U.S. Highway } 2 \text { near Florence, } \\
\text { MI }^{1}\end{array}$ & $\begin{array}{l}1914-16 \\
1945-\text { present }\end{array}$ & 366 & 111.2 & 3.15 & 349.9 & .00098 \\
\hline 04065500 & Sturgeon River near Foster City, MI ${ }^{1}$ & 1955-1980 & 237 & 96.5 & 3.45 & 333.4 & .00027 \\
\hline
\end{tabular}

${ }^{1}$ Data collected by Michigan Department of Natural Resources (Mistak and Stille, 2007)

${ }^{\dagger}$ Operated as a crest-stage partial-record station.

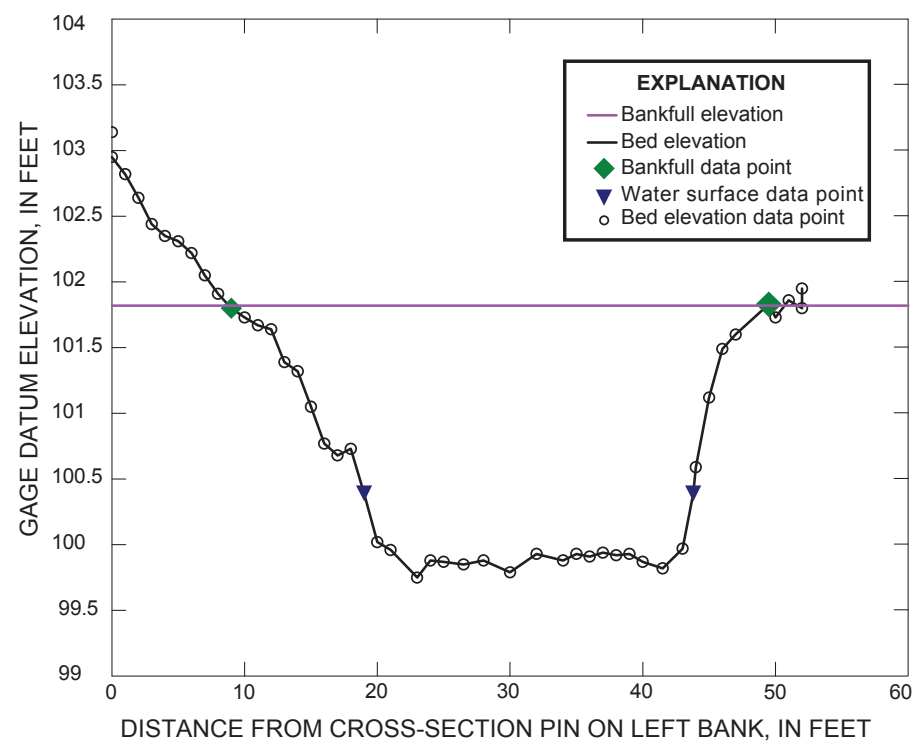

Figure 7. Riffle cross-section data collected at USGS streamgage 04161580 Stony Creek near Romeo, Michigan. 


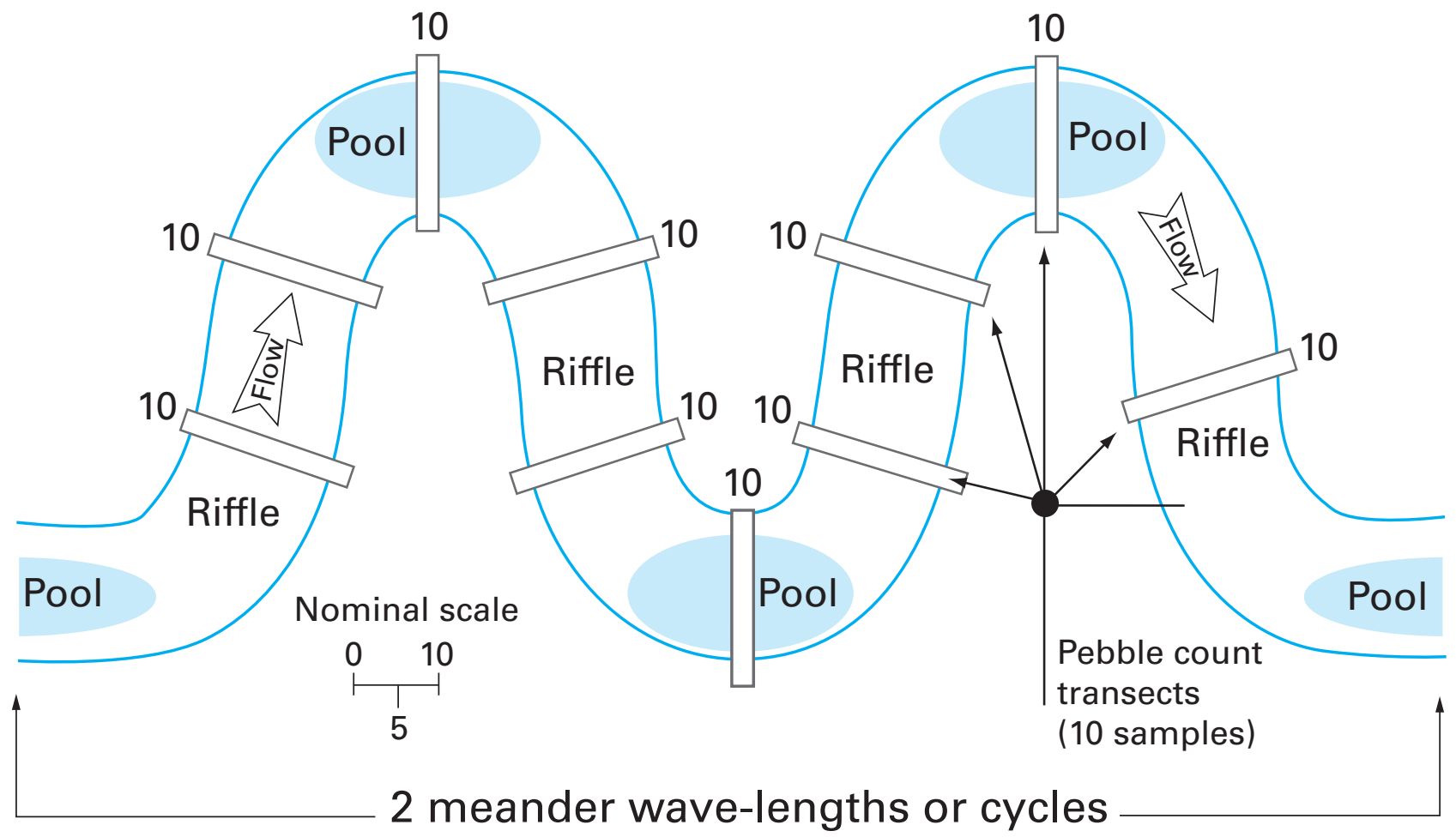

Figure 8. Schematic diagram of generic reach average pebble-count survey distribution based upon available stream features (modified from Rosgen, 1996).

To ensure data accuracy and to test the reproducibility of the cross-section dataset by different survey teams using the same data-collection protocol, USGS streamgage 04046000 Black River near Garnet was surveyed independently by two teams during the first season of data collection. One crosssection survey was conducted by each team at the same riffle (fig. 9). Overall, the measurements were within 20 percent of each other, except for the pebble-count data (table 5). After the data were reviewed, a discrepancy was found in how the pebble-count surveys were conducted by the two teams. One team emphasized conducting the 100-count pebble survey bankfull-to-bankfull in an equal-distance manner, and the other team emphasized placing the majority of the surveyed pebbles within the wetted-channel width. The Michigan Stream Team decided to conduct pebble-count surveys equaldistance bankfull-to-bankfull, regardless of the water-surface elevation during the day of the survey. This is based on the premise that the cross-sectional pebble counts should reflect bankfull conditions, when the exposed bars and bank face would be inundated. Pebble-count data collected previous to this comparison was not reanalyzed.

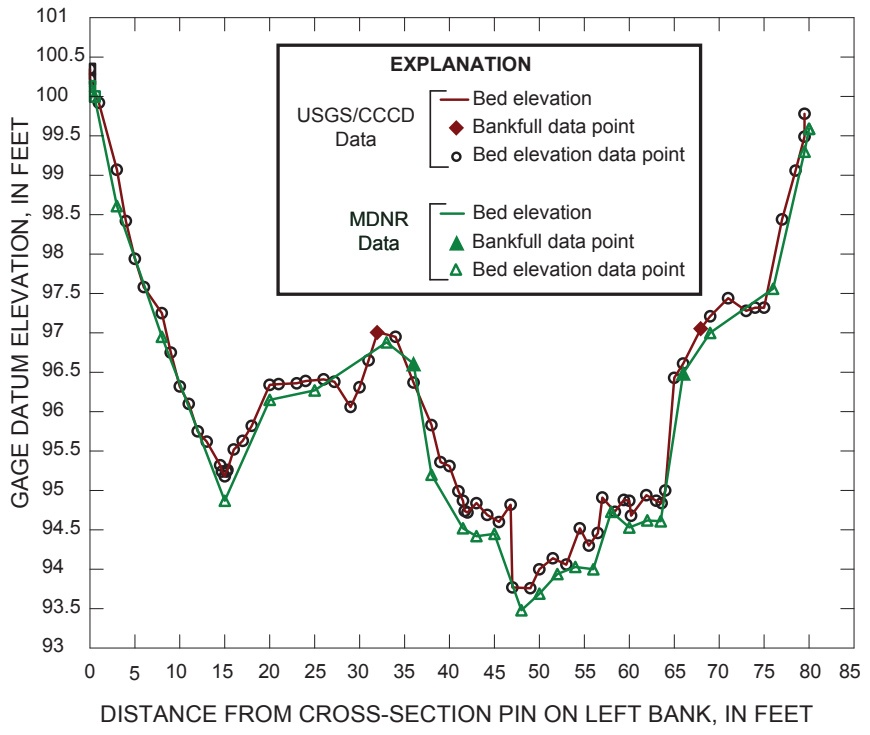

Figure 9. Comparison of riffle cross-section data collected at U.S. Geological Survey streamgage 04046000 Black River near Garnet, Michigan, by two independent survey teams. 
Table 5. Comparison of survey data collected at U.S. Geological Survey streamgage 04046000 Black River near Garnet, Michigan.

[ft, foot; $\mathrm{ft}^{2}$, square foot; $\mathrm{D} 84,84^{\text {th }}$ percentile particle size; $\mathrm{mm}$, millimeter; USGS, U.S. Geological Survey; CCCD, Calhoun County Conservation District; MDNR, Michigan Department of Natural Resources]

\begin{tabular}{cccccc}
\hline $\begin{array}{c}\text { Survey } \\
\text { team }\end{array}$ & $\begin{array}{c}\text { Bankfull } \\
\text { width } \\
\text { (ft) }\end{array}$ & $\begin{array}{c}\text { Bankfull } \\
\text { depth } \\
(\mathbf{f t})\end{array}$ & $\begin{array}{c}\text { Bankfull } \\
\text { cross- } \\
\text { sectional } \\
\text { area } \\
\left.\mathbf{f t t}^{2}\right)\end{array}$ & $\begin{array}{c}\text { Water- } \\
\text { surface } \\
\text { slope } \\
(\mathbf{f t} / \mathrm{ft})\end{array}$ & $\begin{array}{c}\text { D84 } \\
(\mathbf{m m})\end{array}$ \\
\hline $\begin{array}{c}\text { USGS/ } \\
\text { CCCD }\end{array}$ & 35.9 & 1.89 & 68.0 & 0.01788 & 342 \\
$\begin{array}{c}\text { MDNR } \\
\text { Percent } \\
\text { difference }\end{array}$ & 29.9 & 2.10 & 62.8 & .01992 & 143 \\
\hline
\end{tabular}

\section{Bankfull Discharge Comparison to Flood-Frequency Statistics}

Bankfull discharge was calculated for all stable stream reaches surveyed by use of the cross-sectional area determined from the riffle cross-section summary data and water-surface slope estimated from the longitudinal profile data. The discharge equation used was derived by Riggs (1976):

$$
\log Q=0.53+1.295 \log A+0.316 \log S
$$

where

$$
\begin{aligned}
Q & =\text { discharge }\left(\mathrm{m}^{3} / \mathrm{s}\right) ; \\
A & =\text { cross-sectional area }\left(\mathrm{m}^{2}\right) ; \\
S & =\text { energy grade-line slope. }
\end{aligned}
$$

Riggs postulated this approach for calculating discharge because it eliminates the need to define a channel-roughness coefficient, which he suggested was prone to inconsistencies. These inconsistencies were owing to lack of an objective way to assign a single roughness coefficient based on physical characteristics (such as bed roughness, bank irregularity, vegetation, water depth, and channel slope) and owing to inaccuracies in the measurement of variables used in the Manning equation (Riggs, 1976). Using data for known slope and roughness coefficients, Riggs observed that the two were strongly correlated, enabling his derivation of equation 1. Application of antilogs and conversion of equation 1 from metric units into English units yielded:

$$
Q_{b f}=5.514 * A_{b f}^{1.295} * S^{0.316},
$$

where

$$
\begin{aligned}
Q_{b f}= & \text { discharge }\left(\mathrm{ft}^{3} / \mathrm{s}\right), \text { assumed in this study to be } \\
& \text { equal to the bankfull discharge; } \\
A_{b f}= & \text { cross-sectional area }\left(\mathrm{ft}^{2}\right) ; \\
S \quad & \text { energy grade-line slope, assumed in this } \\
& \text { study to be approximated by the water- } \\
& \text { surface slope }(\mathrm{ft} / \mathrm{ft}) .
\end{aligned}
$$

Tables 6-9 present the estimated bankfull discharges and their corresponding flood-recurrence intervals. In 2005, as previously mentioned, the MDEQ performed a peak-flow analysis for selected USGS streamgaging stations and provided floodrecurrence estimates. In 2008, the MDEQ reran the analysis to include stations that were not part of the original 2005 analysis and to provide an expanded range of flood-recurrence intervals for some sites where this information was not provided in the initial report (Fongers, 2008). Comparison of the estimated bankfull discharges to the flood-recurrence intervals shows that bankfull discharges in Michigan recur less frequently than every 2 years at only a few sites, with most of the surveyed stations experiencing bankfull discharge more frequently than every 2 years.

Outlier data not apparent in the field-data analysis were identified and investigated through the discharge analysis. For three surveyed sites, the estimated bankfull discharge corresponded closely to the 10-year recurrence interval range of the peak-flow analysis (tables 6-8). These sites are 04046000 Black River near Garnet, 04117500 Thornapple River near Hastings, and 04123000 Big Sable River near Freesoil. At a fourth site, the estimated bankfull discharge at 04164150 North Branch Clinton River near Meade corresponded with the 2-year recurrence interval of the peak-flow analysis (table 6); however, the riffle dimensions were not comparable with those surveyed at other streamgages of similar drainage basin size (table 1). The following are possible explanations for the overestimation of bankfull discharge. The water-surface slope at the surveyed reach of the Black River near Garnet station was 0.01788 and with features that were more similar to a step-pool stream than a riffle-pool stream. Development of the Riggs equation relied on water-surface slopes that ranged from 0.00032 to 0.0181 (Riggs, 1976) and a correlation was assumed between slope and channel roughness. At the Black River station, the slope was at the upper limit originally evaluated for the Riggs equation and many of the pools were shaped by large cobbles and boulders. These two characteristics may make application of the Riggs equation inappropriate for use at this station. The drainage area for the streamgage at Thornapple River near Hastings is at $385 \mathrm{mi}^{2}$, which is the second largest drainage area of all the sites surveyed. However, a lake-level control structure located less than 2 mi upstream of the study reach may have a larger affect on the flood frequency than originally thought. The Big Sable River near Freesoil streamgage was discontinued in 1975. The assumption made for this study is that the peak-flow analysis of the most recently available flow data, in this case from 1942 to 1975, is still representative of current conditions. This assumption may not hold at this particular station because drainage-basin conditions may have changed since records were last kept for this site. The North Branch Clinton River near Meade site is located in an area where land uses are shifting from agriculture to residential and urban, and is adjacent to a golf course. Subsequent visits to the site revealed signs that the river through this reach may have been altered as evidenced by side channels that may represent a previous channel location. This site may have been modified to accommodate the grounds of the golf course and surrounding farms and subdivisions. 
Table 6. Surveyed streamgages, estimated bankfull discharge, and discharge-recurrence interval for the Southern Lower Michigan Ecoregion.

[USGS, U.S. Geological Survey; $\mathrm{ft}^{3} / \mathrm{s}$, cubic foot per second; MI, Michigan; <, less than]

\begin{tabular}{|c|c|c|c|}
\hline $\begin{array}{l}\text { USGS } \\
\text { station } \\
\text { number }\end{array}$ & Station name & $\begin{array}{c}\text { Bankfull } \\
\text { discharge } \\
\left(\mathrm{ft}^{3} / \mathrm{s}\right)\end{array}$ & $\begin{array}{l}\text { Recurrence } \\
\text { interval } \\
\text { (years) }\end{array}$ \\
\hline 04096015 & Galien River near Sawyer, MI & 274 & $<1.005$ \\
\hline 04096340 & St. Joseph River at Clarendon, MI & 346 & 1.05 \\
\hline 04096400 & St. Joseph River near Burlington, MI & 661 & 2 \\
\hline 04096405 & St. Joseph River at Burlington, MI & 341 & 1.05 \\
\hline 04096515 & South Branch Hog Creek near Allen, MI & 116 & 1.05 \\
\hline 04096600 & Coldwater River near Hodunk, MI & 859 & 1.25 \\
\hline 04097170 & Portage River at W Avenue near Vicksburg, MI & 144 & 1.25 \\
\hline 04097370 & Flowerfield Creek at Flowerfield, MI & 100 & 10 \\
\hline 04097540 & Prairie River near Nottawa, MI & 193 & 1.05 \\
\hline 04102776 & Middle Branch Black River near South Haven & 378 & 1.25 \\
\hline 04103010 & Kalamazoo River near Marengo, MI & 639 & 2 \\
\hline 04104945 & Wanadoga Creek near Battle Creek, MI & 59 & 1.005 \\
\hline 04105700 & Augusta Creek near Augusta, MI & 80 & 1.11 \\
\hline 04108600 & Rabbit River near Hopkins, MI & 233 & 1.005 \\
\hline 04111379 & Red Cedar River near Williamston, MI & 261 & 1.005 \\
\hline 04111500 & Deer Creek near Dansville, MI & 161 & 1.25 \\
\hline 04114498 & Looking Glass River near Eagle, MI & 846 & 1.25 \\
\hline 04117500 & Thornapple River near Hastings, MI & 4,415 & 10 \\
\hline 04146063 & South Branch Flint River near Columbiaville, MI & 403 & 1.01 \\
\hline 04150500 & Cass River at Cass City, MI & 1,246 & $<1.05$ \\
\hline 04159900 & Mill Creek near Avoca, MI & 779 & 1.25 \\
\hline 04160600 & Belle River at Memphis, MI & 1,438 & 2 \\
\hline 04160800 & Sashabaw Creek near Drayton Plains, MI & 69 & 2 \\
\hline 04161580 & Stony Creek near Romeo, MI & 187 & 5 \\
\hline 04161760 & West Branch Stony Creek near Washington, MI & 83 & 1.5 \\
\hline 04164050 & North Branch Clinton River at 33 Mile Road near Romeo, MI & 187 & 1.01 \\
\hline 04164150 & North Branch Clinton River near Meade & 1,224 & 2 \\
\hline 04172500 & Portage River at Tiplady Road near Pinckney, MI & 92 & 1.05 \\
\hline
\end{tabular}


Table 7. Surveyed streamgages, estimated bankfull discharge, and discharge-recurrence interval for the Northern LacustrineInfluenced Lower Michigan Ecoregion.

[USGS, U.S. Geological Survey; $\mathrm{ft}^{3} / \mathrm{s}$, cubic foot per second; MI, Michigan; $<$, less than]

\begin{tabular}{|c|c|c|c|}
\hline $\begin{array}{l}\text { USGS } \\
\text { station } \\
\text { number }\end{array}$ & Station name & $\begin{array}{l}\text { Bankfull } \\
\text { discharge } \\
\left(\mathrm{ft}^{3} / \mathrm{s}\right)\end{array}$ & $\begin{array}{l}\text { Recurrence } \\
\text { interval } \\
\text { (years) }\end{array}$ \\
\hline 04122230 & $\begin{array}{l}\text { North Branch Pentwater } \\
\quad \text { River near Pentwater, MI }\end{array}$ & 194 & 1.25 \\
\hline 04123000 & $\begin{array}{l}\text { Big Sable River near } \\
\text { Freesoil, MI }\end{array}$ & 498 & 10 \\
\hline 04124500 & $\begin{array}{l}\text { East Branch Pine River near } \\
\text { Tustin, MI }\end{array}$ & 415 & 2.33 \\
\hline 04125460 & $\begin{array}{l}\text { Pine River at High School } \\
\text { Bridge near Hoxeyville, } \\
\text { MI }\end{array}$ & 881 & 1.5 \\
\hline 04128000 & $\begin{array}{l}\text { Sturgeon River near } \\
\text { Wolverine, MI }\end{array}$ & 502 & $<1.25$ \\
\hline 04129500 & Pigeon River at Afton, MI & 393 & $<1.25$ \\
\hline 04135700 & $\begin{array}{l}\text { South Branch Au Sable River } \\
\text { near Luzerne, MI }\end{array}$ & 661 & 2 \\
\hline
\end{tabular}

Table 8. Surveyed streamgage, estimated bankfull discharge, and discharge-recurrence interval for the Northern LacustrineInfluenced Upper Michigan and Wisconsin Ecoregion.

[USGS, U.S. Geological Survey; $\mathrm{ft}^{3} / \mathrm{s}$, cubic foot per second; MI, Michigan]

\begin{tabular}{cccc}
\hline $\begin{array}{c}\text { USGS } \\
\text { station } \\
\text { number }\end{array}$ & Station name & $\begin{array}{c}\text { Bankfull } \\
\text { discharge } \\
\left(\mathbf{f t}^{3} \mathbf{s}\right)\end{array}$ & $\begin{array}{c}\text { Recurrence } \\
\text { interval } \\
\text { (years) }\end{array}$ \\
\hline 04046000 & Black River near Garnet, MI & 365 & 10 \\
\hline
\end{tabular}

Table 9. Surveyed streamgaging stations, estimated bankfull discharge, and discharge-recurrence interval for the Northern Continental Michigan, Wisconsin, and Minnesota Ecoregion.

[USGS, U.S. Geological Survey; $\mathrm{ft}^{3} / \mathrm{s}$, cubic foot per second; MI, Michigan; $<$, less than]

\begin{tabular}{cccc}
\hline $\begin{array}{c}\text { USGS } \\
\text { station } \\
\text { number }\end{array}$ & Station name & $\begin{array}{c}\text { Bankfull } \\
\text { discharge } \\
\left(\mathbf{f t}^{3} \mathbf{s} \text { ) }\right.\end{array}$ & $\begin{array}{c}\text { Recurrence } \\
\text { interval } \\
\text { (years) }\end{array}$ \\
\hline 04033000 & $\begin{array}{c}\text { Middle Branch Ontonagon } \\
\text { near Paulding, MI }\end{array}$ & 791 & 2 \\
04060500 & Iron River at Caspian, MI & 575 & 2.33 \\
04060993 & $\begin{array}{c}\text { Brule River at U.S. Highway } \\
\text { 2 near Florence, MI }\end{array}$ & 1,216 & 1.5 \\
04065500 & $\begin{array}{c}\text { Sturgeon River near Foster } \\
\text { City, MI }\end{array}$ & 760 & $<1.25$ \\
\hline
\end{tabular}

In addition to the four streamgages described that were excluded from analysis, three other surveyed sites were identified that should not be used for regional reference curve delineation: 04040500 Sturgeon River near Sidnaw, 04057510 Sturgeon River near Nahma Junction, and 04065600 Pine Creek near Iron Mountain. These sites are within the Northern Continental Michigan, Wisconsin, and Minnesota Ecoregion. At the Sturgeon River near Sidnaw streamgage, bedrock was identified immediately downstream of the study reach, although it was not observed within the reach itself. Data collected at the Sturgeon River near Nahma Junction streamgage is documented in Mistak and Stille (2007); the pebble- count distribution shows that 14 percent of the riffle and reachaverage data and 5 percent of the pool data are composed of bedrock. Near-surface and at-surface outcropping of bedrock may be acting as a control on the pattern and profile of the study reach, which may explain the poor correlation of data collected at these sites to that of nearby stations. At the Pine Creek near Iron Mountain streamgage, a strip mine and associated tailings pond are within $5 \mathrm{mi}$ upstream of the study reach. These features may affect the flow regime and channel geometry within the study reach; therefore, this site has been eliminated from the analysis.

\section{Regional Hydraulic Geometry Curves}

By use of the statistical software package S-Plus, a simple nonlinear regression analysis was performed in which the riffle cross-section summary data - bankfull width, depth, and cross-sectional area-were the dependant variables and drainage area was the independent variable (table 1; Insightful, 2005). As part of this approach, for a power function in the form of $Y=a X^{b}, Y$ is the dependant variable, $X$ is the independent variable, and $a$ and $b$ are optimized. The resulting equation is then graphed with the data using the optimized $a$ and $b$ values and 95-percent confidence intervals of the model. The axes of the graph are converted from arithmetic to log, and residual data are used to calculate the corresponding coefficients of determination (fig. 10).

By use of this approach, hydraulic geometry equations relating bankfull width, depth, and cross-sectional area were delineated for the 26 stations within the Southern Lower Michigan Ecoregion:

$$
\begin{aligned}
& \text { Width }=8.19 \times \mathrm{DA}^{0.44}\left(\mathrm{R}^{2}=0.69\right) \\
& \text { Depth }=0.67 \times \mathrm{DA}^{0.27}\left(\mathrm{R}^{2}=0.28\right) \\
& \text { Area }=4.38 \times \mathrm{DA}^{0.74}\left(\mathrm{R}^{2}=0.59\right) .
\end{aligned}
$$

Using the estimated discharges, a regional hydraulic geometry curve for bankfull discharge in the Southern Lower Michigan Ecoregion was delineated (fig. 11). The equation for this curve is:

$$
\text { Discharge }=4.05 \times \mathrm{DA}^{0.95}\left(\mathrm{R}^{2}=0.60\right)
$$




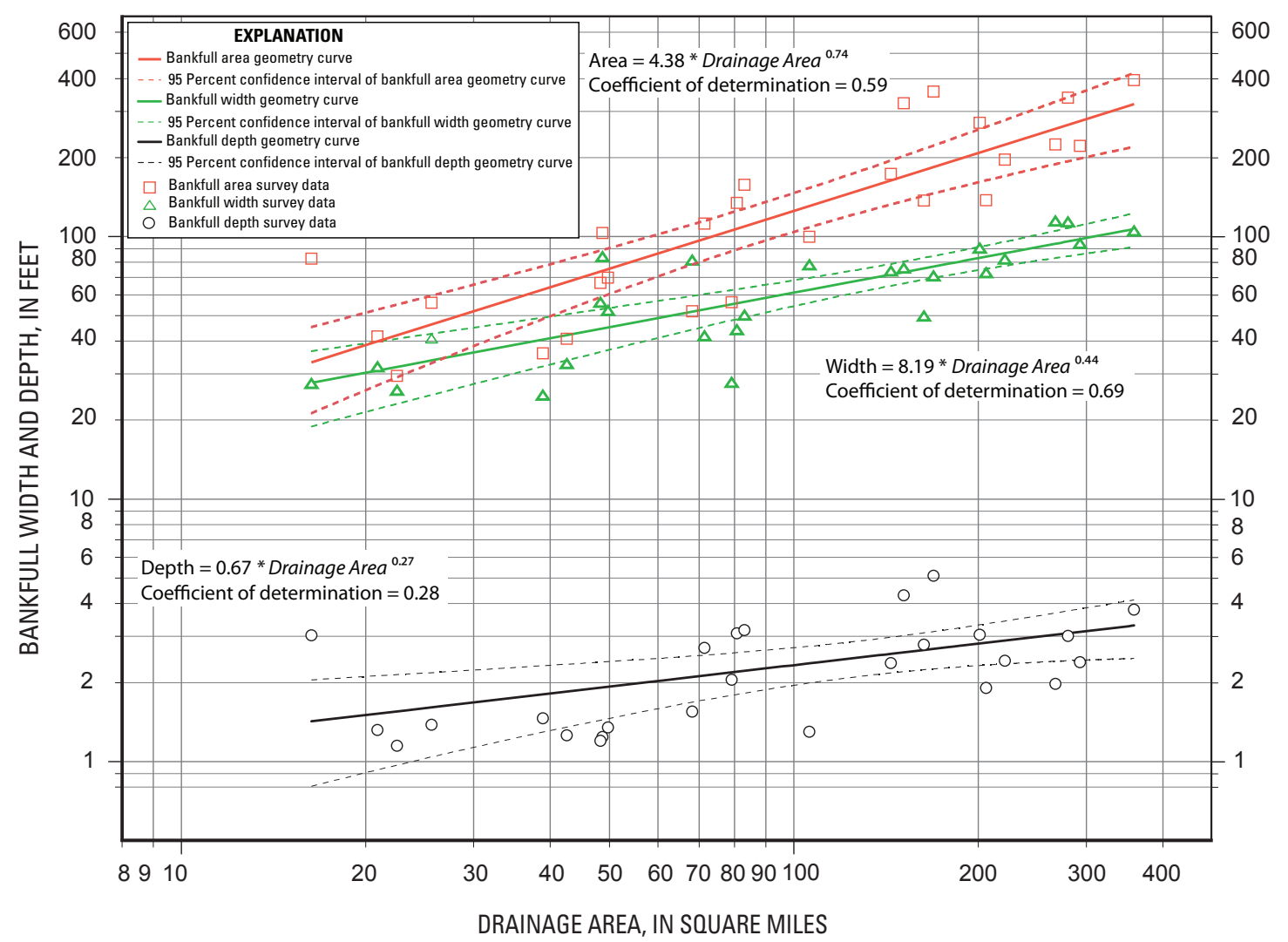

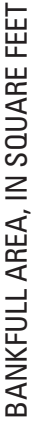

Figure 10. Regional bankfull width, depth, and area curves for the Southern Lower Michigan Ecoregion.

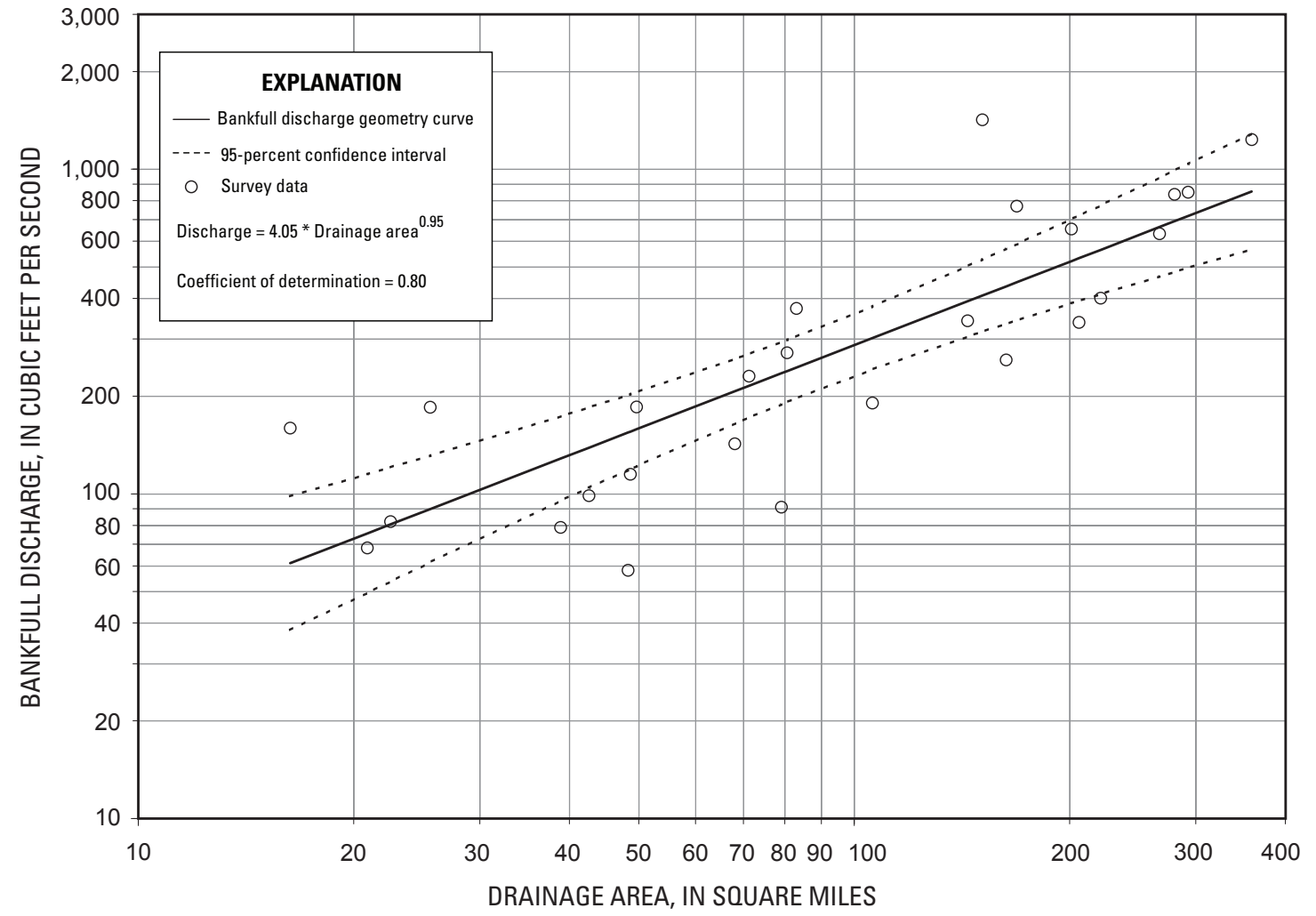

Figure 11. Regional bankfull discharge curve for the Southern Lower Michigan Ecoregion. 


\section{Summary and Conclusions}

Regional hydraulic geometry curves, also commonly called "regional reference curves," are regression curves that describe the relation between stream-riffle characteristics and basin size. Riffle characteristics used to generate hydraulic geometry curves are bankfull width, bankfull depth, bankfull cross-sectional area, and bankfull discharge. Longitudinal profile, cross-sectional, and pebble-count survey data were collected at 43 U.S. Geological Survey (USGS) streamgaging stations. By use of the riffle cross-section geometry data and water-surface slope measured from the longitudinal profile, bankfull discharge was estimated and compared to floodrecurrence intervals. This comparison shows that bankfull discharges in Michigan recur more frequently than every 2 years. The discharge analysis also identified three stations that were not appropriate for use in delineating regional hydraulic geometry curves.

For this study, all USGS streamgages in Michigan with a period of record at least 10 years or longer, with stream reaches unaffected by manmade structures or previous channel alterations, and with slope or channel geometry not controlled by bedrock were considered as possible survey sites. Based on field reconnaissance, many sites were eliminated owing to site conditions. Of the 43 stable stream reaches surveyed, 28 were within the Southern Lower Michigan Ecoregion, and the remaining 15 were spread within the remaining three ecoregions in Michigan. There were not enough data to delineate individual regional hydraulic curves for each ecoregion so hydraulic geometry curves were developed only for the Southern Lower Michigan Ecoregion (SLME).

The curves for the SLME yielded nonlinear regression equations relating bankfull width, depth, and cross-sectional area to drainage area. These equations and their coefficients of determination $\left(\mathrm{R}^{2}\right)$ are as follows, where $D A$ is drainage area:

$$
\begin{aligned}
& \text { Width }=8.19 \times D A^{0.44} ; \mathrm{R}^{2}=0.69 \\
& \text { Depth }=0.67 \times D A^{0.27} ; \mathrm{R}^{2}=0.28 \\
& \text { Area }=4.38 \times D A^{0.74} ; \mathrm{R}^{2}=0.59 .
\end{aligned}
$$

By use of estimated bankfull discharges, a nonlinear regression equation was developed that relates bankfull discharge to drainage area for the SLME. This equation and its coefficient of determination are:

$$
\text { Discharge }=4.05 \times D A^{0.95} ; \mathrm{R}^{2}=0.60 .
$$

\section{References Cited}

Albert, D.A., 1995, Regional landscape ecosystems of Michigan, Minnesota, and Wisconsin-A working map and classification: St. Paul, Minn., U.S. Department of Agriculture, Forest Service, North Central Forest Experiment Station, General Technical Report NC-178, $250 \mathrm{p}$.

Bergquist, S.G., 1936, The Pleistocene history of the Tahquamenon and Manistique drainage region of the Northern Peninsula of Michigan: State of Michigan Geological Survey Publication 40, Geological Series 34, pt. I, 148 p.

Boley-Morse, K., 2009, A classification of stream types at reference reach USGS gage stations in Michigan: East Lansing, Michigan State University, Masters thesis [variously paged].

Croskey, H.M., and Holtschlag, D.J., 1983, Estimating generalized flood skew coefficients for Michigan: U.S. Geological Survey Water-Resources Investigations Report 83-4194, $27 \mathrm{p}$.

Daly, C.W., Gibson, P., Taylor, G.H., Johnson, G.L., and Pasteris, P., 2002, A knowledge-based approach to the statistical mapping of climate: Climate Research, v. 22, p. 99-113.

Doonan, C.J., and Henrickson, G.E., 1969, Ground water in Ontonagon County, Michigan: State of Michigan Geological Survey Water Investigation 9 Report, 29 p.

Fongers, D., 2008, Peak Flow analysis of Michigan USGS gages: Lansing, Mich., Michigan Department of Environmental Quality Land and Water Management Division, Hydrologic Studies Unit Report, 14 p., accessed November 20, 2008, at http://www.michigan.gov/deq/0,1607,7-1353313_3684_41228-141575--,00.html

Francis, J.T., and Haas, R.C., 2006, Clinton River Assessment: Lansing, Mich., Michigan Department of Natural Resources, Fisheries Division Special Report, 97 p., accessed March 24, 2009, at http://www.michigandnr.com/ PUBLICATIONS/PDFS/ifr/ifrlibra/special/reports/sr39/ sr39 text.pdf

Insightful Corporation, 2005, S-Plus 7 for Windows User's Guide: Seattle, Wash., Insightful Corporation, 664 p. 
Jarrett, R.D., 1985, Determination of roughness coefficients for streams in Colorado: U.S. Geological Survey WaterResources Investigations Report 85-4004, 60 p.

Leopold, L.B., and Maddock, T., 1953, The hydraulic geometry of stream channels and some physiographic implications: U.S. Geological Survey Professional Paper 252, 57 p.

Michigan Information Center, 2001, Land area and population density for places in Michigan, April 1, 2000: Lansing, Mich., State of Michigan History, Arts, and Libraries, accessed April 1, 2009, at http://www.michigan.gov/ hal/0,1607,7-160-51170 $51886 \quad 51889---, 00 . h t m l$

Michigan Stream Team, 2005, Protocol for field surveys of stream morphology at gaging stations in Michigan: Lansing, Mich., 38 p., accessed December 7, 2005, at http:// www.michigan.gov/deq/0,1607,7-135-3313_3684_41228141575--,00.htm

Mistak, J.L., and Stille, D.A., 2007, Upper Menominee River Regional Curve: Marquette, Mich., Michigan Department of Natural Resources, 19 p, accessed January 25, 2007, at http://www.michigan.gov/deq/0,1607,7-1353313_3684_41228-141575--,00.html

Passero, R.N., Straw, W.T., and Schmaltz, L.J., 1981, Hydrogeologic atlas of Michigan: Western Michigan University, College of Arts and Sciences, Department of Geology, $35 \mathrm{pl}$.
Rantz, S.E., and others, 1982, Measurement and computation of streamflow-Volume 1, Measurement of stage and discharge: U.S. Geological Survey Water Supply Paper 2175, $284 \mathrm{p}$.

Riggs, H.C., 1976, A simplified slope-area method for estimating flood discharges in natural channels: Journal of Research of the U.S. Geological Survey, v. 4, no. 3, p. 285-291.

Rosgen, D.L., 1994, A classification of natural rivers: Catena, v. 22, p. 169-199.

Rosgen, D.L., 1996, Applied river morphology: Pagosa Springs, Colo., Wildland Hydrology, 388 p.

Sherwood, J.M., and Huitger, C.A., 2005, Bankfull characteristics of Ohio streams and their relation to peak streamflows: U.S. Geological Survey Scientific Investigations Report 2005-5153, 38 p.

Soller, D.R., and Packard, P.H., 1998, Digital representation of a map showing the thickness and character of Quaternary sediments in the glaciated United States east of the Rocky Mountains: U.S. Geological Survey Digital Data Series DDS-38, CD-ROM. 
This page is intentionally blank. 

몸

들.

9 Printed on recycled paper 